\title{
USING MULTIPLE BEHAVIORAL CRITERIA TO ASSESS BUFFALOES ON-FARM WELFARE
}

\author{
S. Elkaschab, S. Omar, Elham M. Ghoneim and E. Eldahshan \\ Department of Animal Production, Faculty of Agriculture, Menufia University.
}

Received: Dec. 25, 2016

Accepted: Jan. 3, 2017

\begin{abstract}
The present study was carried out at the research unit for animal behaviour, faculty of agriculture, Minufiya University, Egypt. This farm unit could be representing the main production systems in Egypt which used traditionally extensive production systems. The main aim of this research was to using multiple behavioral criteria to assess animal's on-farm welfare. Fifty three Egyptian buffaloes, distributed according to production status and its age (18 dairy buffalo cows, 14 heifers and 21 growing calves) were kept in closed housing system in individual tie-stall barn with hard surface. The experiment lasted one year from august 2014 to July 2015 representing different seasons; during this period buffaloes were video recorded for $72 \mathrm{~h}$. Imonth with a total observation time of 864 hours for each animal using complete digital behavioural observation unit. Animal rectal temperature, pulse rate, respiration rate and serum cortisol level were estimated monthly after observation period. Results revealed that the suggested behaviour models for Egyptian buffaloes for lying, eating and ruminating bouts were 75.34, 30.90 and $27.04 \mathrm{~min}$. /time resp., Representing 47.04, 28.31 and 30.95\% of the day and frequent 8.99, 13.19 and 16.48 times per day with the same previous order. Egyptian buffaloes have $37.71^{\circ} \mathrm{C}$ as rectal temperature, 26.42 (breath/min) for respiration rate, 63.36 (beat $\left./ \mathrm{min}\right)$ for pulse rate and $4.45[\mathrm{ng} / \mathrm{ml}]$ for serum cortisol. All previous physiological parameters were within normal range. There were some factors affected studied criteria such as season and animals status.
\end{abstract}

Key words: Animal welfare, Egyptian buffalo, animal behaviour, physiological parameters, serum cortisol

\section{INTRODUCTION}

Mechanization and the implementation of new technologies (Intensive production) have resulted in major increases in efficiency of production. Consequently cattle are susceptible to a variety of stress factors; rough handling can cause them to become apprehensive of people and to be stressed in their presence, and poor housing conditions can lead to illnesses which may be directly linked to stress. The concept of quality has now broadened greatly to take account of the effects of production systems on human health, animal welfare and the environment.

The welfare of an animal has been defined by Fraser and Broom (1990) as its state at it seeks to cope with its environment. Welfare principally concerns both the physical and psychological wellbeing of an animal, which is largely determined by the standard of stockman ship, the system of husbandry and the suitability of the animal for the environment (FAWC, 2009). At present, some monitoring systems have been developed in Europe for assessing welfare at farm level. These include the animal welfare index TGI35L in Austria (Bartussek, 2001) and the related TGI200 in Germany (Sundrum, 2001). In addition, the development of a monitoring system for assessing buffalo welfare at farm level is needed either to provide a certification system for comparing different husbandry systems or as an advisory/management tool for the farmer. Unfortunately, few studies have been conducted on this issue. 
Behavioral changes are the most manifest symptoms of poor welfare Candiani et al. (2008). The study and observation of behavior and the animals themselves has become an important tool in identifying situations where their welfare is compromised (Bracke $\mathrm{m}$ et al. 2001). Therefore, the main aim of this research was to using multiple behavioral criteria to assess animals on-farm welfare.

\section{MATERIALS AND METHODS}

The present study was carried out at the research unit for animal behaviour, belonging to the Faculty of Agriculture, Minufiya University, Egypt. This farm unit could be representing the main production systems in Egypt which used traditionally extensive production systems. The milk production level of the dairy buffaloes in this Unit reach an average of $2000 \pm 300 \mathrm{~kg} /$ lactation period which represents the average of milk yield in Egyptian buffaloes (El kaschab, 1998).

\section{Buffalo Herd and Management}

The herd of studied buffaloes consists of a total numbers of 53 animals distributed according to production status and its age as follows: 18 dairy buffalo cows (after weaning calves), 14 heifers (15-20 month old) and 21 growing calves (from weaning up to 10 month of age). Animals were kept in closed housing system in individual tie-stall barn measured $1.2 \times 1.7 \mathrm{~m}$. with hard surface. The lighting was adequate to monitoring the animals at the day while industrial dim lighting was used at night. Feeding regime was practiced as follows: during the period from December to May, animals were feed an Egyptian clover (Trifolium alexandrinum), concentrate mixture and rice straw, while they fed clover hay, concentrate mixture and rice straw during the rest of the year. Concentrate mixture was offered according to their maintenance and productive requirements according to NRC (1985). Roughage was presented ad-lib twice daily. Water was available ad lib from automatic drinkers. Concentrate mixture was delivered during milking times for dairy animals while other animals feed on concentrate mixture twice daily at 6 am and $6 \mathrm{pm}$. Machine milking was performed twice daily (at 5 am and 5 pm) using portable, milking machine.

The experiment was conducted during one year from august 2014 to July 2015 representing different seasons (Table 1). During this period buffaloes were video recorded for $72 \mathrm{~h}$. /month with a total observation time of 864 hours for each animal using complete digital behavioural observation unit, which consists of 4 digital observation camera, digital storage unit and control unit. Continuous observation methods were used to record the activity patterns of each animal during observation periods.

\section{Studied Criteria Daily activities}

A. Frequency and total period of lying behaviour: Lie was defined as all legs relaxed with underside in contact with the floor (Weimer, 2012).

B. Frequency and total period of eating behaviour: defined as feeding in mouth, chewing, or head down in the manger close to the feed (Alzahal et al., 2006).

C. Frequency and total period of ruminating behaviour: defined as the time when the animals were not eating and were rechewing the bolus (Mezzalira et al., 2012).

\section{Physiological parameters:}

Ambient temperature and relative humidity were recorded twice daily in animal farm, at observed days, with digital portable thermo-hygrometer. Temperature humidity index (THI) was computed according to the following National Research Council formula [NRC 1971] 


\section{Using multiple behavioral criteria to assess buffaloes on-farm welfare}

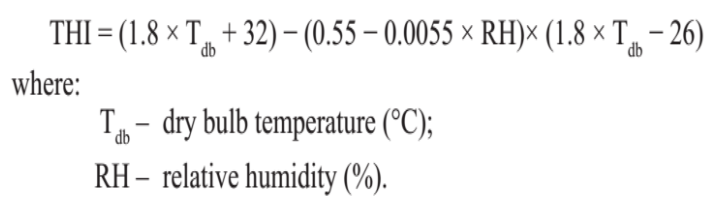

Animal rectal temperature was recorded using thermometer. Pulse rate and respiration rate were taken for 1 min. with stopwatch by counting tail artery beats and flank movements. To estimate serum cortisol hormone level, Blood samples were collected from the jugular vein into test tubes and they were kept at room temperature for 30 to $60 \mathrm{~min}$ and then centrifuged at 3500 rpm for 10 minutes. After centrifugation, serum was stored in a deep freezer at $-20^{\circ} \mathrm{C}$ till analysis. Cortisol level was estimated using ELISA kit at commercial lab. Rectal temperature, Pulse rate, respiration rate and serum cortisol hormone level were estimated monthly after observation period.

\section{Statistical analysis:}

Statistical analyses were conducted to study the effect of season and animal status on studied criteria. Data were analyzed using the general linear model of SPSS (1999).according to the following model:

Where: $Y i j k=\mu+S i+T j+S T i j+e i j k$

Yijk Criteria studied for buffaloes in the ijk subclass;

$\mu \quad$ Overall mean;

$\mathrm{Si}$ The fixed effect due to the $\mathrm{i}_{\text {th }}$ season, $i=1,2,3,4$, where: $1=$ spring
$2=$ summer

$3=$ autumn

$4=$ winter

$\mathrm{Tj}$ The effect due to the $j_{\text {th }}$ animal status, $j=1,2,3$, where: $1=$ dairy buffalo, $2=$ buffalo heifers, $3=$ buffalo calves;

eijk Random error.

Means between different groups were tested by Duncan test (Duncan, 1955).

\section{RESULTS AND DISCUSSION}

Stable climate condition in different seasons (Ambient temperature and relative humidity) were recorded twice daily in animal farm, at each observed milking as shown by Table (1).

\section{Lying behavior}

Means $(\bar{X}) \pm$ standard errors (SE) of lying behaviour was listed in Table (2). It's clearly appears that studied animals lying $8.99 \pm 0.39$ times as an average per day and spent $677.37 \pm 15.07$ minutes in lying position throughout the day representing $47.04 \%$ of each day. This duration almost within normal range as accepted by previous studies (De Rosa et al., 2009, Elaref , 2006 and Omar,1988) who noted that buffalo cows spent $789.12 \mathrm{~min}, 559.71 \mathrm{~min}$. and $702 \mathrm{~min}$. in lying position respectively. The suggested lying bout model for buffaloes in the present study was $75.34 \mathrm{~min}$. /bout.

Table (1): Stable climate condition in different seasons.

\begin{tabular}{|c|c|c|c|l|}
\hline Seasons & Months & $\begin{array}{c}\text { Ambient } \\
\text { temperature }\end{array}$ & $\begin{array}{c}\text { Relative } \\
\text { humidity }\end{array}$ & \multicolumn{1}{|c|}{ THI } \\
\hline Spring & March, April and May & $23.70^{\circ} \mathrm{C}$ & $53.62 \%$ & 70.35 \\
\hline summer & June, Julie and august & $29.83^{\circ} \mathrm{C}$ & $65.60 \%$ & 80.19 \\
\hline autumn & September, October and November & $24.59^{\circ} \mathrm{C}$ & $65.39 \%$ & 72.62 \\
\hline winter & December, January and February & $17.80^{\circ} \mathrm{C}$ & $59.00 \%$ & 62.51 \\
\hline
\end{tabular}


Elkaschab, et al.,

Table (2): Means $(\bar{X}) \pm$ standard errors (SE) of lying behaviour.

\begin{tabular}{|c|c|c|c|c|c|}
\hline & & & & \\
\hline & tudied factors & $\begin{array}{c}\text { Observation } \\
\mathrm{N}\end{array}$ & $\begin{array}{c}\text { Lying } \\
\text { Frequency } \\
\bar{X} \pm \text { SE (time) }\end{array}$ & $\begin{array}{c}\text { Total Lying } \\
\text { period/day } \\
\bar{X} \pm \mathrm{SE} \text { (min.) }\end{array}$ & $\begin{array}{c}\text { Total lying } \\
\text { period in (\%) }\end{array}$ \\
\hline & neral mean $(\mu)$ & 1614 & $8.99 \pm 0.39$ & $677.37 \pm 15.07$ & 47.04 \\
\hline & Spring & 414 & $9.73^{\mathrm{ab}} \pm 0.53$ & $729.44^{b} \pm 21.20$ & 50.65 \\
\hline ธ్ & Summer & 387 & $11.33^{b} \pm 0.56$ & $736.61^{b} \pm 16.30$ & 51.15 \\
\hline$\underset{\mathbb{E}}{\mathscr{E}}$ & Autumn & 390 & $7.93^{\mathrm{a}} \pm 0.33$ & $709.44^{b} \pm 26.29$ & 49.26 \\
\hline & Winter & 423 & $7.00^{\mathrm{a}} \pm 1.25$ & $534.00^{a} \pm 49.52$ & 37.08 \\
\hline & Sig. & & 0.01 & 0.05 & \\
\hline$\sum_{0}^{\infty}$ & Dairy buffaloes & 354 & $8.52^{\mathrm{a}} \pm 1.08$ & $672.77 \pm 21.08$ & 46.72 \\
\hline $\begin{array}{l}\infty \\
\frac{\infty}{\pi}\end{array}$ & Heifers & 504 & $9.32^{b} \pm 1.22$ & $681.22 \pm 29.57$ & 47.31 \\
\hline 言 & Calves & 756 & $9.16^{b} \pm 0.97$ & $678.10 \pm 18.34$ & 47.09 \\
\hline & Sig. & & 0.05 & NS & \\
\hline
\end{tabular}

a ,b, c means within each column with different superscript differ significantly

NS non-significant, $P<0.01$ highly significant and $P<0.05$ significant

Factors affecting lying behaviour.

There was some factors affected lying behavior such as season and animals status. Lying frequency was significantly higher $(P<0.01)$ in summer $(11.33 \pm 0.56)$ than other seasons. Also total Lying period scored the highest value in summer (736.61 min. ) and the lowest in winter (534.00 min.) followed by autumn and spring (709.44 and 729.44 resp.) this depression in winter may be due to bad isolation of concrete hard surface in experiment location. This in agreement with Winckler et al. (2003) who noted that in cattle, an inadequate environment may reduce the ease with which animals change position from standing to lying by increasing the risk of falls and collision against cubicle partitions.

Lying frequency significantly affected by the animal's status $(P<0.05)$. Which was the shortest achieved by dairy buffaloes $(8.52 \pm 1.08$ times/day) followed by calves $(9.16 \pm 0.97$ times/day) then heifers (9.32 \pm 1.22 times/day). Heifers spent more lying period $(681.22 \pm 29.57 \mathrm{~min}$.) than calves and lactating buffaloes (678.10 \pm $18.34 \mathrm{~min}$. and $672.77 \pm 21.08 \mathrm{~min}$. resp.). However differences among three groups were not significant.

\section{Eating behaviour.}

Means $(\bar{X}) \pm$ standard errors (SE) of eating behaviour are listed in Table (3). It's obvious that studied animals spent $407.63 \pm$ 13. $07 \mathrm{~min}$. daily (24 hours) eating, representing $28.31 \%$ of each day, which frequent $13.19 \pm 0.59$ times in average per day. Eating behaviour affected by many factors which could be illustrated the wide range of eating as founded in previous studied. De Rosa et al., (2009) and Elaref (2006) noted that lactating buffalo cows spent $216 \mathrm{~min}$. and $202.26 \mathrm{~min}$. in eating respectively. While Omar (1988), Thind and gill (1986) and Sharma et al., (1978) mentioned that buffalo spent $381 \mathrm{~min}, 349$ min. and $273 \mathrm{~min}$. in eating position respectively. The suggested eating bout model was 30.90 min. per eating time. 
Table (3): Means $(\bar{X}) \pm$ standard errors (SE) of eating behaviour.

\begin{tabular}{|c|c|c|c|c|c|}
\hline & tudied factors & Observation & & $\begin{array}{l}\text { Total eating } \\
\text { period/day }\end{array}$ & Eating period \\
\hline & neral mean $(\mu)$ & 1614 & $13.19 \pm 0.59$ & $407.63 \pm 13.07$ & 28.31 \\
\hline & Spring & 414 & $15.36^{b} \pm 0.43$ & $419.00^{b} \pm 9.18$ & 29.09 \\
\hline ธ & Summer & 387 & $16.94^{b} \pm 0.83$ & $404.00^{b} \pm 19.65$ & 28.05 \\
\hline ஸँ & Autumn & 390 & $6.15^{a} \pm 0.77$ & $288.52^{a} \pm 21.56$ & 20.04 \\
\hline & Winter & 423 & $14.33^{b} \pm 0.33$ & $519.00^{c} \pm 8.18$ & 36.04 \\
\hline & Sig. & & 0.01 & 0.01 & \\
\hline$\sum_{\overparen{D}}^{0}$ & Dairy buffaloes & 354 & $12.63 \pm 1.38$ & $422.70^{b} \pm 12.18$ & 29.35 \\
\hline$\frac{\infty}{\omega}$ & Heifers & 504 & $13.14 \pm 1.22$ & $392.06^{a} \pm 20.47$ & 27.22 \\
\hline "⿳亠二口犬 & Calves & 756 & $13.82 \pm 1.09$ & $408.12^{\mathrm{a}} \pm 11.84$ & 28.34 \\
\hline & Sig. & & NS & 0.05 & \\
\hline
\end{tabular}

a ,b, c means within each column with different superscript differ significantly

NS non-significant, $\mathrm{P}<0.01$ highly significant and $\mathrm{P}<0.05$ significant

\section{Factors affecting eating behaviour.}

Eating frequency and eating period significantly affected by season. Lowest frequency and duration scored in autumn (6.15 times and $288.52 \mathrm{~min}$. resp.). However the highest duration was in winter (519.00 min.). This trend may be refers to ambient temperature decrease, The best recognized effect of heat stress is an adaptive depression of metabolic rate associated with reduced appetite (Silanikove, 2000), and high feed stuffs quality availability in winter, but only eating period significantly affected by animal status. Lactating animals were the most group scored eating period (422.70 $\pm 12.18 \mathrm{~min}$.).

\section{Ruminating activities.}

Table 4 shows least square means \pm standard errors $(\bar{X} \pm \mathrm{SE})$ of ruminating behaviour for Egyptian buffaloes. From this table it could be mentioned Egyptian buffaloes spent $445.72 \pm 22$. $07 \mathrm{~min}$. representing $30.95 \%$ of the day in ruminating and frequency was $16.48 \pm 1.39$ times. Previous studies by De-Rosa et al. (2009), Elaref 2006, Omar 1988, Thind and Gill (1986) mentioned that ruminating duration of buffaloes were 388.8, 419.69, 539 and $490 \mathrm{~min}$. per day respectively. Some studies show that the rumination pattern and changes in rumination may be used to evaluate the responses of animals to acute stressors (Schirmann et al., 2011). The suggested ruminating bout model was 27.04 min. per ruminating time. 
Elkaschab, et al.,

Table (4): Means $(\bar{X}) \pm$ standard errors (SE) of ruminating behaviour.

\begin{tabular}{|c|c|c|c|c|c|}
\hline \multicolumn{2}{|c|}{ Studied factors } & $\begin{array}{c}\text { Observation } \\
{[N]}\end{array}$ & $\begin{array}{c}\text { ruminating } \\
\text { Frequency } \\
\bar{X} \pm \text { SE (time) }\end{array}$ & $\begin{array}{c}\text { Total ruminating } \\
\text { period/day } \\
\bar{X} \pm \text { SE (min.) }\end{array}$ & $\begin{array}{l}\text { Ruminating } \\
\text { period in (\%) }\end{array}$ \\
\hline \multicolumn{2}{|c|}{ General mean $(\mu)$} & 1614 & $16.48 \pm 1.39$ & $445.72 \pm 22.07$ & 30.95 \\
\hline \multirow{4}{*}{ 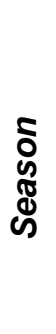 } & Spring & 414 & $16.24 \pm 2.04$ & $445.44^{b} \pm 17.14$ & 30.93 \\
\hline & Summer & 387 & $18.44 \pm 0.93$ & $489.32^{b} \pm 28.42$ & 33.98 \\
\hline & Autumn & 390 & $14.26 \pm 1.14$ & $345.44^{a} \pm 17.14$ & 23.99 \\
\hline & Winter & 423 & $17.00 \pm 2.00$ & $502.67^{\mathrm{b}} \pm 22.55$ & 34.91 \\
\hline \multicolumn{2}{|r|}{ Sig. } & & NS & 0.01 & \\
\hline \multirow{3}{*}{ 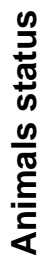 } & Dairy buffaloes & 354 & $15.84 \pm 0.88$ & $453.24 \pm 23.11$ & 31.47 \\
\hline & Heifers & 504 & $16.42 \pm 1.02$ & $435.35 \pm 31.52$ & 30.23 \\
\hline & Calves & 756 & $17.19 \pm 0.97$ & $448.56 \pm 18.14$ & 31.15 \\
\hline \multicolumn{2}{|r|}{ Sig. } & & NS & NS & \\
\hline
\end{tabular}

a ,b, c means within each column with different superscript differ significantly NS non-significant, $\mathrm{P}<0.01$ highly significant and $\mathrm{P}<0.05$ significant

\section{Factors affecting ruminating behaviour.}

Ruminating behaviour did not affected by season or animals status unless ruminating period significantly affected by season, buffaloes scored the lowest frequency and duration in autumn (14.26 times and 345.44 min. respect.) and the highest duration was in winter (502.67 min.).Spring and summer had intermediate values (445.44 and 489.32 min. resp.). This finding was in agreement with that reported by (Collier et al. 1982) they noted that heat stress in high-producing lactating dairy cows results in a dramatic reduction in rumination.

\section{Modeling welfare physiological parameters}

using

Some physiological parameters that could be indicating animal welfare are illustrated in Table (5). It clearly appears that Egyptian buffaloes have $37.71 \pm 0.03{ }^{\circ} \mathrm{C}$ as Rectal temperature, $26.42 \pm 0.22$ (breath/min) for respiration rate, $63.36 \pm$ 0.24 (beat $/ \mathrm{min}$ ) for pulse rate and $4.45 \pm 0.65$ $[\mathrm{ng} / \mathrm{ml}]$ for serum cortisol. all previous physiological parameters were within normal range. Cohen et al. (1997) noted that Serum cortisol concentrations have been used as physiological marker of stress in domestic animals.

\section{Factors affecting studied physiological parameters}

There was no significant difference in rectal temperature among seasons. On the other hand respiration and pulse rate significantly elevated $(\mathrm{P}<0.05)$ during summer season (28.06 breath $/ \mathrm{min}$. and $65.60 \mathrm{beat} / \mathrm{min}$. resp.) against the others. Serum cortisol scored the highest value 
during summer $(9.13 \mathrm{ng} / \mathrm{ml}$.) and the lowest for spring $(3.90 \mathrm{ng} / \mathrm{ml}$.). Autumn and winter have intermediate value 4.35 and 4.43 $\mathrm{ng} / \mathrm{ml}$. resp.). The previous results agree with Elvinger et al. (1992) they reported that heat stress increased rectal temperature, respiration rates and plasma cortisol concentration, and decreased milk yield of lactating cows. The significant increase in cortisol level in summer heat exposure of buffalo calves may be attributed to the hyper secretion of the adrenal cortex (Nessim, 2010).

Calves Rectal Temperature was the highest (38.03 $\pm 0.12 \mathrm{oc})$ followed by heifers $(37.76 \pm 0.23 \mathrm{oc})$ and dairy buffaloes was the lowest $(37.34 \pm 0.11$ oc) but differences among the groups were not significant.
Respiration rate significantly affected by the animals status $(P<0.05)$ which was $(24.10$ $\pm 0.35,24.11 \pm 0.73$ and $31.06 \pm 0.82$ breath/min) for dairy, heifers and calves, respectively. Animals' status did not have any significant effect on pulse rate.

The highest value of serum cortisol achieved by calves $(6.07 \pm 0.35 \mathrm{ng} / \mathrm{ml})$ followed by heifers $(4.06 \pm 0.42 \mathrm{ng} / \mathrm{ml})$ and finally dairy animals were the lowest $(3.23 \pm 0.75 \mathrm{ng} / \mathrm{ml})$. The differences among groups were highly significant $(P<0.01)$. on the other hand Habeeb et al., (1996) supposed that with increasing milk yield, the increased concentrations of plasma cortisol are associated with the demand of udder for cortisol for milk synthesis.

Table (5): Means $(\bar{X}) \pm$ standard errors (SE) of Rectal Temperature, Respiration rate, Pulse rate and serum cortisol.

\begin{tabular}{|c|c|c|c|c|c|c|}
\hline \multicolumn{2}{|c|}{ Studied factors } & $N$ & $\begin{array}{c}\text { Rectal } \\
\text { Temperature } \\
\left({ }^{\circ} \mathrm{C}\right)\end{array}$ & $\begin{array}{l}\text { Respiration } \\
\quad \text { rate } \\
\text { (breath/min) }\end{array}$ & $\begin{array}{l}\text { Pulse rate } \\
\text { (beat/min) }\end{array}$ & $\begin{array}{c}\text { Serum cortisol } \\
{[\mathrm{ng} / \mathrm{ml}]}\end{array}$ \\
\hline \multicolumn{2}{|c|}{ General mean $(\mu)$} & 538 & $37.71 \pm 0.03$ & $26.42 \pm 0.22$ & $63.36 \pm 0.24$ & $4.45 \pm 0.65$ \\
\hline \multirow{4}{*}{ 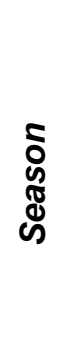 } & Spring & 138 & $37.79 \pm 0.02$ & $26.09 \pm 0.42$ & $61.83 \pm 0.34$ & $3.9 \pm 0.84$ \\
\hline & Summer & 129 & $37.83 \pm 0.02$ & $28.06 \pm 0.35$ & $65.60 \pm 0.44$ & $9.13 \pm 1.34$ \\
\hline & Autumn & 130 & $37.69 \pm 0.04$ & $25.86 \pm 0.34$ & $63.93 \pm 0.36$ & $4.35 \pm 0.92$ \\
\hline & Winter & 141 & $37.55 \pm 0.03$ & $25.66 \pm 0.24$ & $62.08 \pm 1.19$ & $4.43 \pm 0.55$ \\
\hline \multicolumn{2}{|r|}{ Sig. } & & NS & 0.05 & 0.05 & 0.01 \\
\hline \multirow{3}{*}{ 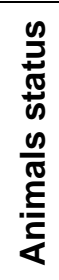 } & $\begin{array}{l}\text { Dairy } \\
\text { buffaloes }\end{array}$ & 118 & $37.34 \pm 0.11$ & $24.10^{b} \pm 0.35$ & $63.57 \pm 0.54$ & $3.23^{c} \pm 0.75$ \\
\hline & Heifers & 168 & $37.76 \pm 0.23$ & $24.11^{b} \pm 0.73$ & $63.29 \pm 1.03$ & $4.06^{b} \pm 0.42$ \\
\hline & Calves & 252 & $38.03 \pm 0.12$ & $31.06^{\mathrm{a}} \pm 0.82$ & $63.20 \pm 0.66$ & $6.07^{\mathrm{a}} \pm 0.35$ \\
\hline \multicolumn{2}{|r|}{ Sig. } & & NS & 0.05 & NS & 0.01 \\
\hline
\end{tabular}

a ,b, c means within each column with different superscript differ significantly NS non-significant, $\mathrm{P}<0.01$ highly significant and $\mathrm{P}<0.05$ significant 


\section{REFERENCES}

Alzahal, H., J.L. Benford, T. Widowski, J.P. Walton, J.C. Plaizier, T. Duffield, N.E. Odongo and B.W. Mcbride (2006). Effects of Frequency of Feed Delivery on Dairy Cattle Behavior. The Professional Animal Scientist . 22 (1): 80-83.

Bartussek, H. (2001). An historical account of the development of the animal needs index ANI-35L as part of the attempt to promote and regulate farm animal welfare in Austria: an example of the interaction between animal welfare science and society. Anim. Sci. 30: 3441.

Bracke, M. B. M., M. H. J. Metz, A. A. Dijkhuizen and M. B. Spruijt (2001). Development of a decision support system for assessing farm animal welfare in relation to husbandry systems: strategy and prototype. J. Agric. Environ. Ethics. 14: 321-337.

Candiani, D., S. Germana, M. Elisabetta, D. Luca, B. Renato, T. Mathilda and G. Erik (2008). A Combination of Behavioral and Physiological Indicators for Assessing Pig Welfare on the Farm. journal of applied animal welfare science,11:1-13.

Cohen, S., RC Kessler and LU Gordon (1997). Measuring stress. A guide for health and social scientists. Oxford Univ. Press New York, NY.

Collier, R.J., D. K. Beede, W. W. Thatcher, L. A. Israel and C. J. Wilcox (1982). Influences of environment and its modification on dairy animal health and production. J Dairy Sci. 65:2213-2227

De Rosa, G., F. Grasso, A. Braghieri, A. Bilancione, A. Di Francia and $F$. Napolitano (2009). Behavior and milk production of buffalo cows as affected by housing system. J Dairy Sci. 92 (3): 2009.

El kaschab, S. (1998). Milk Production: Published by Al Dar al Arabia for Publishing \& Distribution I.S.B.N. 977258-130-2.
Elaref, M. (2006). Some behavioural aspects to evaluate buffaloes housing systems. Thesis of master of science in animal production. Faculty of Agriculture., Minufiya University

Elvinger, F., Roger P. Natzke and Peter J. Hansen (1992). Interactions of Heat Stress and Bovine Somatotropin Affecting Physiology and Immunology of Lactating Cows. J. Dairy Science, Volume 75, Issue 2: 449-462.

FAWC, (2009). Farm Animal Welfare in Great Britain: Past, Present and Future. Farm Animal Welfare Council. http://www.fawc.org.uk

Fraser, A. F. and D. M. Broom (1990). Farm Animal behaviour and Welfare. Sannders, New York.

Habeeb, A. A. M., M. KH. Ibrahim and H. M. Yousef (1996). Milk and Blood Cortisol and T3 Hormones Content and Milk Composition in Buffaloes as a Function of Lactating Number and Ambient temperature. Third Arab Conference on the Peaceful Uses of Atomic Energy, Damascus 9-13Dec.

Mezzalira, J. C., Carolina Bremm, Júlio Kuhn Da Trindade, Carlos Nabinger and Paulo César de Faccio Carvalho. (2012). the Ingestive Behaviour of Cattle in Large-scale and Its Application to Pasture Management in Heterogeneous Pastoral Environments. Journal of Agricultural Science and Technology A 2: 909-916.

NRC, National Research Council (1985). Nutrient requirements of sheep, sixth revised National Academy Press, Washington, DC.

NRC, National Research Council (1971). A guide to environmental research on animals. National Academy of Science, Washington, DC.

Nessim, M.Z. (2010). changes in cortisol and some biochemical parameters in blood of egyptian buffalo calves exposed to two successive summer seasons. isotope \& rad. res., 42(2): 315-325. 
Omar, S. S. (1988). Relationship between some behavioural aspects and both productive and reproductive traits in buffaloes and cattle. Ph.D. Agric. (Animal Production), Univ. of Minufiya.

Schirmann, K., N. Chapinal, D. M. Weary, W. Heuwieser and M. A. G. von Keyserlingk (2011). Short-term effects of regrouping on behavior of prepartum dairy cows. J. Dairy Sci. 94:2312-2319.

Sharma, S.C., D. S. Singh, O. P. S. Sengar and S.N. Singh (1978). Eating, ruminating and idling behaviour of farm ruminants. Agra. Univ. j. res., 27: 61-74.

Silanikove, N. (2000). Effects of heat stress on the welfare of extensively managed domestic ruminants. Livest Prod Sci 67:1-18.

Sundrum, A. (2001). Organic livestock farming:A critical review. Livest. Prod. Sci. 67:207-215.
Thind, J. S. and R. S. Gill (1986). Ingestive behaviour of lactation buffaloes kept under loose housing system. Indian J. Dairy Sci.,39: 41-46.

Weimer, S. L. (2012). Animal-human interaction comparing live human observation and digital image evaluation methodologies. A thesis submitted to the graduate faculty in partial fulfillment of the requirements for the degree of Master of Science. lowa State University. Ames, lowa, USA.

Winckler, C., J. Capdeville, G. Gebresenbet, B. Hörning, U. Roiha, M. Tosi and S. Waiblinger (2003). Selection of parameters of on-farm welfareassessment protocols in cattle and buffalo. Anim. Welfare 12:619-624. 


\title{
استخدام معايير سلوكيه متعدده لتقيم راحة الجاموس داخل المزرعه
}

\author{
سمير الخشاب، سعيد عمر، الهام غنيم، السيا الاهشان
}

قسم الانتاج الحيواني - كلية الزراعة - جامعة المنوفية

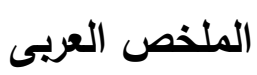

أجريت هذه الدراسة في وحدة ابحاث سلوك الحيوان بكلية الزراعة جامعة المنوفية- مصر . هذه المزرعه تمثل نظام الانتاج الاساسي بمصر حيث الانتاج التقليدي الغير مكثف. وقد اجريت التجربة بغرض استخدام معايير سلوكيه متعدده لتقيم راحة الحيوان داخل المزرعه. استخدم في الدراسه 53 جاموسه مصريه موزعه حسب العمر والحاله الانتاجيه (18 حلاب و 14 عجله و 21 عجول ناميه) سكنت داخل حظائر مغلقه بصوره فرديه في مرابط ذات ارضيه صلبه. استمرت التجربه نحو العام من (اغسطس 2014 حتي يوليو 2015م ) حيث منلت جميع فصول السنه. خلال هذه الفتره تمت مراقبة الحيوانات المدروسه 72 ساعه شهريا لكل حيوان بإجمالى عدد ساعات مراقبه 864 ساعه باستخدام وحدة المراقبة السلوكيه الرقميه. في نهاية كل فترة مراقبه شهريه تم تسجيل درجة حرارة ومعدل نبض ومعدل تتفس وتركيز هرمون الكورتيزول في الدم لكل حيوان. وقد اثارت النتائج ان النموذج المقترح لسلوك الرقاد والاكل والاجترار هو دقيقه/مره على التوالي. حيث بمثل سلوك الرقاد والاكل والاجترار 47,04\% و 28,31\% و 30,95\% من اليوم

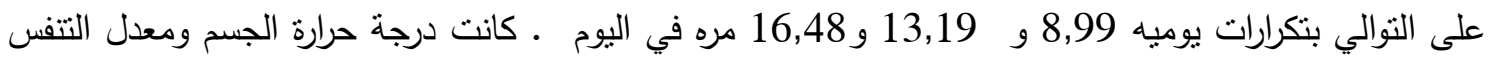

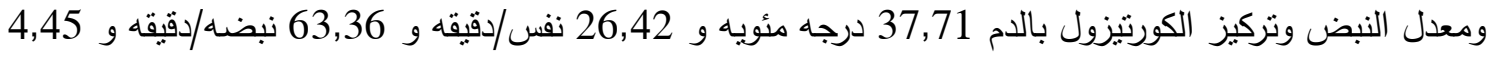
نانوجرام بالملي على التوالي. جميع القياسات الفسيولوجيه السابقه كانت داخل الحدود الطبيعيه. اثر كل من الموسم وحالة الحيوان على بعض الصفات المدروسه. 